\title{
Macroeconomic and Firm Specific Determinants of Stock Returns: A Comparative Analysis of Stock Markets in Sri Lanka and in the United Kingdom
}

\author{
L. M. C. S. Menike', P. M. Dunusinghe ${ }^{2}$, A. Ranasinghe ${ }^{2}$ \\ ${ }^{1}$ Department of Accountancy \& Finance, Faculty of Management Studies, Sabaragamuwa University of Sri Lanka, Belihuloya, Sri Lanka \\ ${ }^{2}$ Department of Economics, Faculty of Arts, University of Colombo, Colombo, Sri Lanka
}

Email address:

lmcsmenike@gmail.com (L. M. C. S. Menike)

\section{To cite this article:}

L. M. C. S. Menike, P. M. Dunusinghe, A. Ranasinghe. Macroeconomic and Firm Specific Determinants of Stock Returns: A Comparative Analysis of Stock Markets in Sri Lanka and in the United Kingdom. Journal of Finance and Accounting. Vol. 3, No. 4, 2015 , pp. 86-96. doi: $10.11648 /$ j.jfa.20150304.14

\begin{abstract}
This paper examines the relationship between macroeconomic and firm-specific determinants of stock returns of Sri Lanka and United Kingdom (UK). Our results are based on the fixed effects regression models since those perform statistically better than the random effects and pooled OLS models for Sri Lankan data and the fitted one-way fixed effects firm factor regression indicates that Return on Assets ( ROA) and sales growth rate play a significant role in explaining variation in stock returns in Sri Lankan companies while one-way random effect firm factor model in UK shows that E/P ratio, B/M ratio, fixed assets growth rate, size and ROA are the most dominants priced factors in London Stock Exchange (LSE). The explanatory power of regressions increases considerably when we incorporate macroeconomic indicators controlling for firm effects and results show that inflation, GDP and exchange rate remain leading predictors of stock returns variation in both Colombo Stock Exchange (CSE) and LSE whereas unemployment and Foreign Portfolio Investments (FPI) become statistically significant only in CSE. Thus, it is noted that stock prices of Sri Lankan and UK companies are sensitive to both company and macroeconomic fundamental changes hence, the stock market analysts and investors find that they can make fundamental base trading strategies as publicly available information play a key role in predicting future returns bringing the conclusions of the Sri Lankan stock market is in semi-strong form efficient in doubt.
\end{abstract}

Keywords: Colombo Stock Exchange, Determinants, London Stock Exchange, Panel Data Regression, Stock Returns

\section{Introduction}

The financial sector of any country plays a pivotal role in the development process of each economy and economy depends on the growth of its financial sector. The key player of the financial sector is the capital market who provides an avenue to the users and providers of the financial resources for investment purposes. Sri Lankan economy has shown a rapid economic growth rate during the last decade and a range of internal and external factors have contributed towards this fast growth. The government has implemented a better regulatory framework and granted incentives to both local and foreign investors internally. The macroeconomic stability of the country attracted the foreign investors in the form of foreign direct investments (FDI) and foreign portfolio investments in order to meet the mounting capital needs in pushing the country to a faster growth rate externally. In addition, Sri
Lankan stock market has emerged as a pleasing market for international investors due to the political stability after the 30 years of civil war restoring the investors' confidence. These enhanced FDI and FPI enriched the key economic indicators during the past decade. All Share Price Index (ASPI) reached its peak in May 2011 historically and market capitalization as a percentage of Gross Domestic Product (GDP) too exhibited a significant enhancement. Moreover, Sri Lanka has been enjoying integration with global stock markets.

It is believed that the movements in the stock prices are affected by changes in fundamentals of the company and economy and the expectations about future prospects of these fundamentals. Thus, the overall economic performance of the country depends on how well the stock market performs and stock market performance depends on numerous factors 
which are highly volatile to macroeconomic and global economic conditions. Investigating the co-movement of economic fundamentals, firm characteristics and stock market performance becomes an important issue in order to bring the country and the stock market to a faster growth path. Empirically, Chen, Roll and Ross (1986) believe that asset prices are commonly believed to react sensitively to economic news and stock prices are usually considered as responding to external forces and by the diversification argument that is implicit in capital market theory, only general economic state variables will influence the pricing of large stock market aggregates.

A variety of financial theories and models have been developed to explain the behavior of stock markets. 1 From the inception of these assets pricing theories researchers empirically investigate whether, either the CAPM or the APT better explains the relationship between the risk and return factors. In the last three decades, numerous empirical studies have tested these theories and examined the dynamic relationships between stock markets and macroeconomic fundamentals and firm fundamentals. They have been widely debated in the finance and macroeconomic literature and most of such studies suggest that financial and macroeconomic variables influence stock returns across a variety of markets and time horizons (Eg; Nasseh and Strauss, 2000; Wonghangpo and Sharma, 2002; and Neri, 2002). Most of these studies are based on well-established stock markets for example US, UK and Japan (Ratanapakorn and Sharma, 2007; Luintel and Pandyal, 2005; and Mukherjee and Naka, 1995). Some other studies focused on various other markets. 2 The results of all these studies suggest that, with minor degrees of variation, basic macroeconomic dynamics is indeed influential factors for stock market returns. The empirical literature also reveals that researchers apply different econometric instruments.

The cross-sectional return predictability has been well documented in well developed and emerging capital markets using various firm characteristics such as size, leverage, book to market ratio, price-earnings ratio, dividend payout ratio and capital expenditure (Lam, 2002; Chan, Lakonishok and Sougiannis, 2001; Leu, Lee and McInish, 2002). However, only few studies in Sri Lankan context, focuses on examining the impact of macroeconomic variables on stock market performance (eg. Gunasekarage et al., 2004; Samarakoon, Hasan and Hasan, 2000 and Wickramasinghe, 2011). To the best of researcher's knowledge none of the studies in Sri Lankan context specifically focused on identifying the macroeconomic and firm-specific determinants of stock returns within a single econometric model so far which accommodates both time series and cross-sectional data and the study fill this gap in Sri Lankan Context.

The empirical studies show that the results are not consistent over countries and are mixed which is country specific and over time the impact has been changed; For instance, country-specific events occur such as terrorist attacks. The size of the country, stock market regulations, and number of firms listed on the stock exchanges, foreign participation, policy implications are all country specific. This requires a country specific study and this study seeks to identify the macroeconomic and firm-specific determinants of stock returns in Sri Lanka. We find that the lessons from Sri Lanka as an emerging market highly require a parallel comparison with a well developed stock market and a comparison is carried out with UK stock market to formulate better strategies to improve economic fundamentals, stock market performance and consequently stability of the economy. Thus, the study seeks to measure the risk premia attached to various macroeconomic and firm-specific factors that influence the returns on assets, whether they are significant, and whether they are "priced" into stock returns in the CSE and the LSE and how they differ from each country. Therefore, the major objective of the study is to identify the determinants of stock returns in Sri Lanka and UK. The rest of the paper is planned as follows: Section 2 provides a review of existing literature on the determinants of stock returns, 3 discusses the data and methodology while the section 4 examines the estimations and discussions on the Sri Lankan and UK stock market. Section 5 undertakes the comparative analysis of the determinants of the stock returns of Sri Lanka and the UK while section 6 gives the concluding remarks.

\section{Review of Literature}

\subsection{Empirical Tests on Firm Specific Factors and Stock Market Returns}

The capital asset pricing model has been subjected to extensive empirical testing in the past 30 years. In 1990s and 2000 s, researchers did not stop looking at other characteristics of stocks which determine the stock returns besides their market factor. Continuing the size effect first reported by Banz (1981), Ho, Strange and Piesse (2000) in the Hong Kong market and Leu, Lee and McInish (2002) in Singapore and Malaysia documented that firms with large market capitalization had lower average returns than firms with small market capitalization. Fama and French (1992) drew further attention to the size effect by sorting stocks by both size and beta and show that high-beta stocks have no higher returns than low-beta stocks of the same size. Lam (2002) and Pandey (2001) found that size plays a dominant role in the expected stock returns.

Several authors found a value effect that returns are predicted by ratios of market value to accounting measures such as earnings, the book value of equity, and the book-to-market ratio. Fama and French (1992) show that firms with higher book-to-market ratios subsequently have higher returns. Chan, Hamao, and Lakonishok (1991) and Dennis, Perfect, Snow and Wiles (1995) reach the same conclusion on book-to-market equity. Fama and French (1998) found that there is a strong positive relation between average return and book-to-market equity for 1929-1963. Lam (2002) reported B/M seemed able to explain stock returns in Hong Kong stock market with the Fama-French approach. Daniel and Tittman (1997) found a significant negative relationship 
between Market-to-Book ratio and stock returns. However, evidence from a study by Davis, Fama and French (2000) shows a positive relationship between Book to Market ratio and stock returns while Tudor (2009) finds that B/M ratio has a significant positive relationship with returns in the univariate regression but loses its significance in the multivariate setting. Many previous studies have documented the price-earnings ratio as a predictor variable of stock returns. Basu (1977) examined the relationship between price/earnings ratios and investment results and finds lowest price/earnings ratio quintile had the highest average annual rate of return. Fama and French (1988) and Lakonishok, Shleifer and Vishny (1994) all confirmed Basu's findings. White (2000) reports similar findings for a longer sample period (1926-1997). Fama and French (1992) and Fuller (1993) show that firms with higher PE ratios subsequently have higher returns while Tudor (2009) finds that $\mathrm{E} / \mathrm{P}$ ratio has a strong positive impact on stock returns.

Most of the recent research concludes that an investment on fixed assets is an influential factor in determining stock returns in many countries. Cooper, Gulen and Schill (2008) find a strong inverse relationship between the firm asset growth and the future stock returns. They associate their findings to investor mis-reaction to assets growth. Titman, Wei and Xie (2004), and Beneish, Lee, and Tarpley (2001) also find that firms with high capital investments subsequently have low returns due to an overinvestment tendency of corporate managers and investors under-reaction to information. Chan, Lakonishok and Sougiannis (2001) found a positive relationship between capital expenditure and stock returns.

The capital structure has become a firm-specific factor of determining stock returns in several studies. Bradshaw, Sloan and Richardson (2006) decomposed firms' external financing activities into two variables: external equity financing and debt financing and they reported that these two variables are negatively correlated with future stock returns, and they attribute this pattern to investor optimism and firms' efforts to time the market in raising capital. Fama and French (1992) also provide evidence that leverage is positively related to expected returns while Lam (2002) document that leverage seemed to be able to explain stock returns in the Hong Kong stock market with the Fama-French approach.

\subsection{Empirical Tests on Macroeconomic Variables and Stock Market Returns}

Fama (1981) documents a strong positive correlation between common stock returns and real variables, such as the capital expenditure, industrial production, the GNP, the money supply, lagged inflation and interest rate. Bulmash and Trivoli (1991) find that the US current stock price is positively correlated with the previous month's stock price, money supply, recent federal debt, recent tax-exempt government debt, long-term unemployment, the broad money supply and the federal rate. However, there is a negative relationship between stock price and the Treasury bill rate, the intermediate lagged federal debt and the recent monetary base.
Mukherjee and Naka (1995) investigate the relation between Tokyo stock prices and six macroeconomic variables and show that the relationship between stock prices, the exchange rate, money supply, and industrial production is positive, whereas the relationship between stock prices and inflation and interest rates is mixed.

Wonghangpo and Sharma (2002) investigates the role of selected macroeconomic variables on the stock prices in the ASEAN countries and they observe that, in the long run, the stock prices are positively related to growth in output and negatively to the aggregate price level. In their study, Ibrahim and Aziz (2003) analyze the linkage between stock prices and four macroeconomic variables discovering that there is a positive short-run and long-run relationship between stock prices with inflation while stock prices have negative association with money supply and the exchange rate. Flannery and Protopapadakis (2002) find that stock market returns are significantly correlated with inflation and money growth estimating a GARCH model on 17 macro series announcements and find six candidates for price factors; three nominal (CPI, PPI, and a monetary Aggregate) and three real (Balance of trade, employment report, and housing starts) in USA. Maysami, Howe and Hamzah, (2004) in Singapore, find a positive relationship between inflation rate and stock returns consistent with the Fisher Hypothesis. The relation between money supply and stock return is also found to be positive. Phylaktis and Ravazzolo (2005) examine the long-run and short-run relationships between stock prices and exchange rate and their evidence suggest that the exchange rate had a significant positive impact on stock returns. Wickremasinghe (2006) reports that there exists a both short and long-run causal relationship among stock prices and macroeconomic variables in Sri Lanka. Gan, Lee, Yong and Zhang (2006) suggest that there exist a long term relationship between stock prices and macroeconomic variables in New Zealand and the impact of inflation rate and money supply on stock prices is found to be negative.

Kim (2003) employed monthly data on stock prices and exchange rates discovering a strong negative relationship between the value of the U.S. dollar and the change in stock prices. Ibrahim and Aziz (2003) and Doong, Yang and Wang (2005) analyze the linkage between stock prices and exchange rate, discovering that stock prices have a negative association with the exchange rate. Using US and Japanese data, Humpe and Macmillan (2007) document that there exist a long run positive relation between stock and industrial production and negative association related to both the consumer price index and long-term interest rate in US, while stock prices are influenced positively by industrial production and negatively by the money supply in Japan. Ratanapakorn and Sharma (2007) propose that the stock prices negatively related to the long-term interest rate, and positive relationship between stock prices and the money supply, industrial production, inflation, the exchange rate and the short-term interest rate. They conclude that in the Granger causality sense, every macroeconomic variable causes the stock prices in the long-run but not in the short-run. Pilinkus and Boguslankas 
(2009) conclude that gross domestic product and money supply have a positive effect on the stock market prices whereas unemployment rate, exchange rate, and short-term interest rates negatively influence on stock market prices. More recently Alam and Uddin (2009) examined evidence supporting the existence of the share market efficiency based on the monthly data for fifteen developed and developing countries and for all the countries it is found that interest rate has significant negative relationship with share prices. Anayochukwu (2012) shows that foreign portfolio investment has a positive and significant impact on stock market returns whereas inflation rate has positive but insignificant impact on stock market returns in Nigeria.

\section{Methodological Approach}

\subsection{The Data}

The data for 107 companies out of 287 listed companies in the CSE as at the end of 2012 were obtained from the annual reports of individual companies and the sample selection is based on several criteria3 and our filters on the CSE consist of 107 sample companies within fourteen sectors 4 with 1391 firm year observations. The sample covers financial statement data from 1999 to 2011 and stock return data from 2000 to 2012. The stock return predictors (financial ratios) were constructed using accounting information at the end of year $\mathrm{t}-1$ and these ratios were linked with stock returns in year $\mathrm{t}$ since there is a time lag between the reporting and the receiving of that information by investors. The study gathered financial data of the LSE listed companies from Bloomberg Database and there were 2487 listed companies as at end July 2013. The same filtering criteria were applied for the selection of the sample companies from the LSE as was applied in the Sri Lankan context. It was noticed that almost all the companies in the LSE are frequently trading and, in order to choose the final sample, the filtered companies on the above selection criteria were ranked on the criterion of liquidity (the highest $40 \%$ of the value of shares traded treated as frequently trading firms) in the LSE. Thus, the UK final sample consists of 228 companies within thirty six sectors, thereby creating 1824 firm year observations. A series of systematic risk factors such as economic factors and financial factors were employed as pervasive factors that seem to be influenced prices of stocks based on the simple and intuitive financial theory. Thus, the study selects the GDP, the exchange rate, the money supply, the inflation, the interest rate, the FDI, the FPI, the crude oil prices and the unemployment rate data on annual basis from the Annual Reports of the Central Bank of Sri Lanka whereas the data of the same macroeconomic indicators in the UK context were obtained from the DataStream except for the crude oil price data gathered from the Office for National Statistics, UK.

The missing values were replaced with an average value. Firms with negative E/P ratios were replaced with zero since the negative E/P ratio is meaningless. Finally, the smallest and the highest $3 \%$ of the observations were equalized with the next smallest/highest observation in order to remove the influence of extreme values in panel data regressions. The general finance theory and intuition are the main inputs used in the variable selection process. The macroeconomic and financial factors that have been found to influence stock returns in the past studies and the availability of data are also important inputs in the process of selection of variables. The selection of firm variables is guided by the FF3F factor model and the results of previous studies that have been mostly conducted on the developed capital markets.

\subsection{Model Specification}

\subsubsection{Panel Data}

To investigate the macroeconomic and firm - specific determinants of stock returns in Sri Lanka and UK panel data regression procedure is applied which examines individual effect, time effect, or both and these effects are either fixed or random. A fixed effect model examines whether the intercepts vary across individuals (groups) or time periods, whereas a random effect model explores differences in error variance.

\subsubsection{Fixed Effect Model}

In the fixed effect model, the group effect, or time effect, or both are entered in the model through dummy variables. For example, if only the group effect is entered in the model then it should be included through the dummy variables $d_{1}, d_{2}, \ldots$, $\mathrm{d}_{\mathrm{n}-1}$ assuming that there are $\mathrm{n}$ number of groups. The model can be expressed as:

$$
Y_{i t}=\alpha+\gamma_{1} d_{1}+\gamma_{2} d_{2}+\cdots \ldots \ldots .+\gamma_{n-1} d_{n-1}+x_{i t}^{T}+\epsilon_{i t}(1)
$$

Where $\alpha$ is the intercept, $\mathrm{X}_{\mathrm{it}}$ is a vector of predictors and $\varepsilon_{\mathrm{it}}$ is the error term. Further we assume that $\epsilon_{\mathrm{i}} \sim \mathrm{N}\left(0, \sigma^{2}\right)$. The significance of the group effect in the fixed effect model can be tested using the usual F-test. Similarly, the fixed time effect model can be obtained by including the dummy variable for the time period considered instead the group dummies in model (2). Further, the fixed time and group effect model can be obtained by including dummies for groups as well as for time. The model takes the form.

$$
Y_{i t}=\alpha+\mu_{i}+T_{t}+\cdots \ldots \ldots+x_{i t}^{T} \beta+\epsilon_{i t}
$$

Where $\mu_{\mathrm{i}}$ and $T_{\mathrm{t}}$ represents the $i^{\text {th }}$ group effect and $\mathrm{t}^{\text {th }}$ time effect respectively. Note that, the parameters can be estimated using the OLS method.

\subsubsection{Random Effect Model}

In the fixed effect model, the mean component is decomposed into group effect and/or time effect and effect from other predictor variables. However, in the random effect model, the variability is separated due to group effect, time effect and error. That is, we estimate variance components for groups (or time) and error. Thus, explore differences in error variances.

The functional form for the random group effect model is

$$
Y_{i t}=\propto+X_{i t}^{T} \beta+u_{i}+\epsilon_{i t}
$$

Where 


$$
\mathrm{u}_{\mathrm{i}} \sim \mathrm{N}\left(0, \sigma_{\mathrm{g}}{ }^{2}\right) \text { and } \mathrm{C}_{\mathrm{it}} \sim \mathrm{N}\left(0, \sigma^{2}\right)
$$

Similarly the functional form for the random time effect model is

$$
Y_{i t}=\propto+X_{i t}^{T} \beta+v_{t}+\epsilon_{i t}
$$

Where

$$
\mathrm{v}_{\mathrm{i}} \sim \mathrm{N}\left(0, \sigma_{\mathrm{T}}{ }^{2}\right) \text { and } \mathrm{C}_{\mathrm{it}} \sim \mathrm{N}\left(0, \sigma^{2}\right)
$$

The two-way random effect model for time and group can be expressed as

$$
Y_{i t}=\propto+X_{i t}^{T} \beta+u_{i}+v_{t}+\epsilon_{i t},
$$

Where

$$
\mathrm{u}_{\mathrm{i}} \sim \mathrm{N}\left(0, \sigma_{\mathrm{g}}^{2}\right) \text { and } \mathrm{v}_{\mathrm{t}} \sim \mathrm{N}\left(0, \sigma_{\mathrm{T}}^{2}\right) \mathrm{C}_{\mathrm{it}} \sim \mathrm{N}\left(0, \sigma^{2}\right)
$$

The parameter in the random effect models can be estimated by generalized least squares (GLS) when the variance structure $\left(\sigma_{g}^{2}, \sigma_{T}^{2}\right.$ and $\left.\sigma^{2}\right)$ is known and by feasible generalized least square (FGLS) when the variance structure is unknown. Compared to fixed effect model, the random effect models are relatively difficult to estimate due to the complex correlation structure. For the two-way random effect model, this is even more so as the data cannot be decomposed into independent sub units.

\subsubsection{Testing the Random Effects}

Breush and Pagan (1980) developed the Lagrange Multiplier (LM) test (Green 2003) to test whether variance components are zero.

$$
H_{0}: \sigma_{g}^{2}=0 \text { Vs } H_{a}: \sigma_{g}^{2} \neq 0
$$

Test statistic:

$$
\begin{gathered}
L M_{g}=\frac{n T}{2(T-1)}\left[T^{2} \frac{\boldsymbol{e}_{g}^{T} \boldsymbol{e}_{g}}{\boldsymbol{e}^{T} \boldsymbol{e}}-1\right]^{2} \sim X_{(i)}^{2} \\
H_{0}: \sigma_{T}^{2}=0 \text { Vs } H_{a}: \sigma_{T}^{2} \neq 0
\end{gathered}
$$

Test statistic :

$$
L M_{T}=\frac{n T}{2(n-1)}\left[n^{2} \frac{\boldsymbol{e}_{T}^{T} \boldsymbol{e}_{T}}{\boldsymbol{e}^{T} \boldsymbol{e}}-1\right]^{2} \sim X_{(i)}^{2}
$$

Where $e_{\mathrm{g}}$ is the $\mathrm{n} \times 1$ vector of group-specific means of pooled regression residuals, $\boldsymbol{e}_{g}^{T} \boldsymbol{e}_{g}$ is the error sum of square of the pooled regression, and $\mathrm{e}_{\mathrm{T}}$ is the $\mathrm{T} \times 1$ vector of time-specific means of pooled regression residuals.

The two-way random effect model has the following hypothesis to test,

$$
H_{0}: \sigma_{T}^{2}=0 \text { and } \sigma_{g}^{2}=0 \text { Vs } H_{a}: \sigma_{g}^{2} \neq 0 \text { or } \sigma_{\mathrm{T}}^{2} \neq 0
$$

\subsubsection{Testing for Fixed or Random Effects}

The Hausman hypothesis test is used only for testing whether the individual random effects are correlated with explanatory variables or not. If there is a correlation between the individual random effects and the explanatory variables, it is concluded that the fixed effect estimator is consistent and efficient; however, the random effect estimator is not consistent (Hausman ve Taylor, 1981). If the null hypothesis of Hausman test is rejected it favors the Fixed Effects estimator's treatment of the omitted effects. If the omitted effects are uncorrelated with the explanatory variables, the Random Effects estimator is consistent and efficient. However, the Fixed Effects estimator is consistent but not efficient. If the effects are correlated with the explanatory variables, the Fixed Effects estimator is consistent and efficient but the Random Effects estimator is inconsistent.

In Hausman test, the following hypotheses are tested:

$$
\mathrm{H}_{0}=E(\mu \mid X)=0 \mathrm{Vs} \mathrm{H}_{\mathrm{a}}=E(\mu \mid X) \neq 0
$$

Where $\mu$ is the unobserved heterogeneity and $\mathrm{X}$ is the explanatory variables.

\section{Estimation and Discussions}

\subsection{Diagnostic Tests}

Given the stationarity of the variables at level, the study finds the macroeconomic and firm- specific determinants of stock returns in Sri Lanka and UK using the pooled OLS, the fixed effect and the random effect regression techniques. All the firm specific and macroeconomic variables are tested for stationarity and the results of Breitung and Harris-Tzavalis unit-root tests reject the null hypothesis of non-stationarity significantly at the level

5. The study incorporates the macro-economic indicators as the determinants of stock returns except firm fundamentals; the multi-collinearity test is performed in order to eliminate the possible correlation among independent variables and it was found that no evidence for the presence of multi-collinearity in any of the regressions performed (Table 2 and 3). The study contains a micro panel with a very few periods of 13 years and the serial correlation test is not performed as they apply to macro panels with long time series over 20-30 years (Baltagi, 2012). Baltagi (2012, p.87) proposes to compute robust standard error correcting for the possible presence of heteroskedasticity and hence, the study calculates robust standard errors in both the fixed and random effects regression models to estimate the efficient regression coefficients6.

\subsubsection{Fisher (F)-Test Results}

The existence of the fixed effects in residuals is tested through $F$ statistic (Panel A and B of Table 1). The F- tests of all the two regressions performed reject the null hypothesis that all dummy parameters are jointly equal to zero and it may be concluded that the fixed firm effect model is better than the pooled OLS model.7 Hence, the fixed effect model is the better choice than the pooled OLS regression model. In the one- way fixed time effect models and the two- way models, no significant time impacts were found and the analysis was conducted only on the one- way fixed firm and random effects models and the results are presented in Tables 2 and 3 . 


\subsubsection{Lagrange Multiplier (LM)-Test Results and Hausman Specification Test Results}

Based on the least squares residuals, the obtained Lagrange Multiplier test statistics for Sri Lankan and UK data (Panel A and B of Table 1) strongly reject the null hypothesis; the random effects model is favored, hence it can be concluded that the classical regression model (Pooled OLS) with a single constant term is not appropriate for these data. The model 1 and 2 under panel A of the table 1 shows the value of Hausman-Statistic for the random firm effect models for Sri Lanka and it can be said that the individual company effects do not have a significant impact on stock return variations in the CSE8 hence, the fixed firm effect models are the most appropriate models in Sri Lankan context. The panel B of table 1 demonstrates the value of Hausman-Statistic for random firm effect models for UK data and the random firm effects model would be the better choice for model 1 under panel B for UK data than its fixed counterpart whereas fixed firm effect model would be more appropriate over its random counterpart for the model 2.

\subsection{Firm Specific Determinants of Stock Returns}

The results of the estimated fixed firm effect model for Sri Lankan data is presented in panel A, model 1 of Table 2 which was regressed on the expected stock returns (dependent variable) with firm explanatory variables - the sales growth rate, the fixed assets growth rate, the Book to Market (B/M) ratio, the Earnings Price $(E / P)$ ratio, the leverage, the size and the Return on Assets .The Return on Assets is an influential variable in determining the stock returns out of the included firm variables in the model and had a strong positive significant association with stock returns in both countries. In Sri Lanka, the results also show that the past sales growth rate makes a positive significant influence on subsequent stock returns at 1 percent significance level implying that the higher the past sales growth is, the higher will be the returns via higher dividends to shareholders. It is evidenced that the past sale growth rate does not significantly influence on subsequent stock returns at all but maintains the significance of other variables retaining it in the model in UK. In UK (See Table 2 pane B), a significant positive relationship is found between the $\mathrm{E} / \mathrm{P}$ ratio and the stock returns at $5 \%$ significance level. This implies that the stocks with high $\mathrm{E} / \mathrm{P}$ ratio perform better than the low $\mathrm{E} / \mathrm{P}$ ratio stocks or the higher the $\mathrm{E} / \mathrm{P}$ ratio is, the higher will be the stock returns. Unfortunately, in Sri Lanka we could not find any statistically significant effect of E/P ratio over stock returns in the fitted firm factor model. The fixed assets growth rate had a significant negative association with stock returns in UK companies. The results of UK firms demonstrate that the $\mathrm{B} / \mathrm{M}$ ratio had a significant negative relationship which is not correctly signed with stock returns at 10 percent significance level. This indicates that the higher the $\mathrm{B} / \mathrm{M}$ ratio is, the lower will be the subsequent returns9 and this negative impact is caused by the overvalued market values during the sample period. On the contrary, the Sri Lankan firms could not show any significant association between the two variables in the firm factor model.

Table 1. Specification Tests.

\begin{tabular}{|c|c|c|c|c|c|c|c|c|}
\hline \multirow{2}{*}{$\begin{array}{l}\text { Model 1: Firm Factors } \\
\text { Specification Test }\end{array}$} & \multicolumn{4}{|c|}{ Panel A - Sri Lanka } & \multicolumn{4}{|c|}{ Panel B-UK } \\
\hline & Statistic & $\mathrm{P}$-value & Tested & Selection & Statistic & $\mathrm{P}$-value & Tested & Selection \\
\hline Hausman & 38.15 & 0.0000 & Fixed/Random & Fixed & 5.61 & 0.34 & Fixed/Random & Random \\
\hline Breusch-Pagen & 15.54 & 0.0001 & OLS/Random & Random & 110.43 & 0.0000 & OLS/Random & Random \\
\hline F-test & 7.78 & 0.0000 & OLS/Fixed & Fixed & 2.24 & 0.0000 & OLS/Fixed & Fixed \\
\hline \multicolumn{9}{|c|}{ Model 2: Firm and Macro Factors } \\
\hline Hausman & 28.12 & 0.0137 & Fixed/Random & Fixed & 30.36 & 0.0002 & Fixed/Random & Fixed \\
\hline Breusch-Pagan & 14.27 & 0.0002 & OLS/Random & Random & 55.93 & 0.0000 & OLS/Random & Random \\
\hline
\end{tabular}

Table 2. Results of the One Way: Fixed (Firm) Effect Model for Sri Lanka and Random (Firm) Effect Model for UK.

\begin{tabular}{|c|c|c|c|c|c|c|c|c|c|c|}
\hline \multirow{2}{*}{$\begin{array}{l}\text { Model -1: Firm Factors } \\
\text { Variable }\end{array}$} & \multicolumn{5}{|c|}{ Panel A - Sri Lanka } & \multicolumn{5}{|c|}{ Panel B -UK } \\
\hline & $\begin{array}{l}\text { Coefficie } \\
\text { nt }\end{array}$ & $\begin{array}{l}\text { Robust } \\
\text { Standard } \\
\text { Error }\end{array}$ & $\begin{array}{l}\text { Z-statis } \\
\text { tic }\end{array}$ & P-value & $\begin{array}{l}\text { Variance } \\
\text { Inflation } \\
\text { Factor }\end{array}$ & Coefficient & $\begin{array}{l}\text { Robust } \\
\text { Standard } \\
\text { Error }\end{array}$ & Z-statistic & P-value & $\begin{array}{l}\text { Variance } \\
\text { Inflation } \\
\text { Factor }\end{array}$ \\
\hline Constant & 0.08 & .0370902 & 3.08 & $0.003 * * *$ & & 163.13 & 64.48 & 2.53 & $0.011 *$ & \\
\hline Sales Growth & 0.01 & .0005881 & 5.08 & $0.000 * * *$ & 1.05 & -0.81 & 0.65 & -1.24 & 0.217 & 1.11 \\
\hline Earnings Price Ratio & 0.001 & .0008453 & 1.14 & 0.256 & 1.01 & 0.95 & 0.42 & 2.28 & $0.023 * *$ & 1.01 \\
\hline Fixed Assets Growth & -0.001 & .0004749 & -0.76 & 0.451 & 1.02 & -0.55 & 0.33 & -1.67 & $0.095 * * *$ & 1.12 \\
\hline Book to Market Ratio & -0.012 & .0093887 & 1.27 & 0.208 & 1.00 & -5.75 & 3.64 & -5.75 & $0.104 * * *$ & 1.00 \\
\hline Return on Assets & 0.008 & .0026706 & 2.82 & $0.006 * * *$ & 1.06 & 13.79 & 6.31 & 2.19 & $0.029 * *$ & 1.00 \\
\hline Leverage & $-5.08 \mathrm{e}-06$ & .0001785 & -0.03 & 0.977 & 1.03 & & & & & \\
\hline Size & 0.068 & .0598158 & 1.14 & 0.258 & 1.01 & & & & & \\
\hline Sigma_e & 0.55 & & & & & 1423.69 & & & & \\
\hline Rho & 0.20 & & & & & 0.13 & & & & \\
\hline Sigma u & 0.27 & & & & & 560.69 & & & & \\
\hline $\mathrm{R}^{2}$ & 0.06 & & & & & 0.05 & & & & \\
\hline
\end{tabular}

Note: $* * * * *$ and $*$ indicate significance at $1 \%, 5 \%$ and $10 \%$ respectively.

Figure in parenthesis indicates p- value of Hausman Statistics.

VIF $>10$ indicates presence of multi-collinearity. 
Further, size and leverage are unable to determine the future stock returns in Sri Lankan companies as shown in panel A of Table 2. All these variables could jointly explain only a 6 percent return variation. The intra-class correlation known as rho is 19 percent which is the variance due to the differences across companies and the total variance due to cross sections is (sigma u) 27 percent. In UK (See Table 2, panel B), these variables could jointly explain only a 5 percent return variation. The intra-class correlation known as rho is 13 percent which is the variance due to differences across panels and the total variance due to cross sections is (sigma $u$ ) 560.69 .

\subsection{Firm Specific and Macroeconomic Determinants of Stock Returns in Sri Lanka and UK}

The fitted fixed firm effects model10 displayed in panel A of Table 3 show that all the firm fundamentals which were highly significant in the model-1 of Table 2 retain their significance in the presence of macroeconomic indicators, namely, inflation, the exchange rate, the FDI, the FPI, the unemployment rate and the GDP in the model for Sri Lankan data. The firm fundamentals namely, sales growth rate and ROA have appeared with the same signs as expected and impact significantly in determining stock returns of the Sri Lankan companies. Surprisingly, in comparison with the firm factor model in Table 2, there appears an improvement in the overall explanatory power of 12 percent captured by all the variables in this model (Table 3, panel A) by incorporating macroeconomic indicators. At the same time, the rho ratio which indicates the cross-sectional return variation out of the total return variation is 14 percent and the standard deviation of residuals within companies (Sigma u) is 22 percent. In UK, the results of the fixed firm effects estimation (Table 3, panel $\mathrm{B}$ ) indicates that the sales growth rate; the $\mathrm{B} / \mathrm{M}$ ratio and the leverage do not have any significant impact on the UK companies' stock returns at all11. The results also show that the E/P ratio positively correlates with the expected stock returns in the UK companies. The market size also appears to have a positive statistically significant association with the stock returns at 10 percent confidence level.

Concentrating with the macroeconomic variables for Sri Lankan data the portfolio flows had a positive and significant relationship with stock returns (see Table 3, panel A), revealing that the increase in portfolio flows will fuel the stock market performance since it creates the investors' confidence. It is well known that the current stock prices are positively related to the future level of the real activity. Thus, as hypothesized GDP growth rate is positively related with the stock returns in both countries (Table 3 ) and highly significant at 1 percent confidence level. In UK, changes in the exchange rates measured by US Dollar/Sterling exchange rate will impact the value of foreign earnings and export performance affecting profits, hence dividends. Thus, the impact of changes in the exchange rate will be determined by the relative dominance of import and export sectors of the economy and as expected, the exchange rate impacts positively on the UK companies' stock returns (See Table 3) and the UK export firms will benefit from the recent years' currency depreciation and the stock prices will go up due to the better performance, hence higher returns. The panel A of Table 3 demonstrates that the exchange rate impacts negatively on stock returns of the Sri Lankan companies at 1 percent significance level.

Table 3. Results of the One Way Fixed (Firm) Effect Model.

\begin{tabular}{|c|c|c|c|c|c|c|c|c|c|c|}
\hline \multirow{2}{*}{$\begin{array}{l}\text { Model 2:Firm and } \\
\text { Macro Variables } \\
\text { Variable }\end{array}$} & \multicolumn{5}{|c|}{ Panel A - Sri Lanka } & \multicolumn{5}{|c|}{ Panel B -UK } \\
\hline & Coefficient & $\begin{array}{l}\text { Robust } \\
\text { Standard } \\
\text { Error }\end{array}$ & Z-statistic & P-value & $\begin{array}{l}\text { Variance } \\
\text { Inflation } \\
\text { Factor }\end{array}$ & Coefficient & $\begin{array}{l}\text { Robust } \\
\text { Standard } \\
\text { Error }\end{array}$ & T-statistic & P-value & $\begin{array}{l}\text { Variance } \\
\text { Inflation } \\
\text { Factor }\end{array}$ \\
\hline Earnings Price Ratio & 0.01 & .0008401 & 1.16 & 0.247 & 1.05 & 0.659 & 0.33 & 1.98 & $0.049 * *$ & 1.01 \\
\hline Book to Market Ratio & -0.01 & .0081016 & -1.30 & 0.196 & 1.01 & -5.13 & 4.10 & -1.25 & 0.212 & 1.00 \\
\hline Sales Growth Rate & 0.01 & .0006101 & 5.11 & $0.000 * * *$ & 1.10 & -0.47 & 0.77 & -0.60 & 0.546 & 1.03 \\
\hline Leverage & 0.01 & .0001725 & 0.28 & 0.778 & 1.03 & 0.35 & 0.32 & 1.10 & 0.274 & 1.01 \\
\hline Size & 0.05 & .0462437 & 1.07 & 0.288 & 1.02 & 36.64 & 20.18 & 1.82 & $0.071 * * *$ & 1.01 \\
\hline Return on Assets & 0.01 & .0023737 & 3.28 & $0.001 * * *$ & 1.07 & & & & & \\
\hline Exchange Rate & -0.02 & .0021264 & -5.07 & $0.000 * * *$ & 3.49 & 5155.68 & 794.71 & 6.49 & $0.000 *$ & 1.57 \\
\hline Inflation & -0.01 & .0012002 & 3.61 & $0.000 * * *$ & 1.07 & -114.63 & 38.17 & -3.00 & $0.003 *$ & 1.14 \\
\hline GDP Growth & 0.05 & .0068478 & 7.31 & $0.000 * * *$ & 1.63 & 202.71 & 24.09 & 8.41 & $0.000 *$ & 1.42 \\
\hline FDI & -0.01 & .0007377 & -1.54 & 0.127 & 1.63 & & & & & \\
\hline FPI & 0.05 & .0068478 & 7.31 & $0.000 * * *$ & 1.64 & & & & & \\
\hline Unemployment & -0.04 & .0183933 & -2.31 & $0.023 * *$ & 4.09 & & & & & \\
\hline GDP & 0.05 & .0068478 & 7.31 & $0.000 * * *$ & 1.63 & & & & & \\
\hline Sigma u & 0.22 & & & & & 722.91 & & & & \\
\hline Sigma e & 0.54 & & & & & 1368.02 & & & & \\
\hline Rho & 0.14 & & & & & 0.2183 & & & & \\
\hline $\mathrm{R}^{2}$ & 0.12 & & & & & 0.09 & & & & \\
\hline
\end{tabular}

Note: $* * *, * *$ and $*$ indicate significance at $1 \%, 5 \%$ and $10 \%$ respectively.

Figure in parenthesis indicates p- value of Hausman Statistics.

VIF $>10$ indicates presence of multi-collinearity.

This reveals that the Sri Lankan import firms will not be benefited from the recent years' currency depreciation and the 
stock prices will go down via profits and dividends due to the increase in the cost of production hence lower returns.

It is evidenced that the stock returns respond inversely to inflation which is strongly statistically significant at 1 percent significance level in both countries (See Table 3).This negative relation may be due the fact that an increase in the inflation rate would influence tight economic policies, hence increases the nominal risk-free interest rate and raises the discount rate in the stock valuation model thereby lowering the stock returns. The results for Sri Lankan data also reveal that the unemployment rate is negatively highly significant at 5 percent level implying that the rising unemployment rate signals fewer cash holdings among investors which are not sufficient to invest in stocks. For UK data as per the fitted fixed effect model in panel $\mathrm{B}$ of Table 3, the results demonstrate that the rho ratio explains 22 percent stock return variation due to the company specific differences and it is quite high compared to all the other rho ratios in the fitted models. Thus, it can be concluded that the individual specific effects of the UK listed companies may lead to higher return variations. The results also show that all these variables could capture a 9 percent stock return variation in UK context.

\section{Market Wise Comparison of Major Findings}

\subsection{Analysis of the Results of the Firm Factors and Stock Returns in the CSE and the LSE}

This section set out to compare and contrast the firm-specific determinants of stock returns in Sri Lanka and the UK so as to investigate which risk factors priced in each stock market and how those factors change across the two countries as an emerging market and a developed market. Interestingly, five firm risk factors, namely, the $\mathrm{E} / \mathrm{P}$, the $\mathrm{B} / \mathrm{M}$, the ROA, the size and the fixed assets growth rate significantly influenced on the UK stock returns whereas the two risk factors, namely, the ROA and the sales growth rate dominated predicting the CSE stock returns significantly. The results show that the ROA remained important predictor of both the CSE and the LSE stock returns. As expected, the E/P ratio impacted positively in UK market implying that the high $\mathrm{E} / \mathrm{P}$ (low $\mathrm{P} / \mathrm{E}$ ) ratio stocks perform better than the low $\mathrm{E} / \mathrm{P}$ (high $\mathrm{P} / \mathrm{E}$ ) ratio stocks. The findings are compatible with the findings of most of the developed markets \{ Fama and French (1988), Lakonishok, Shleifer and Vishny (1994), White (2000) $\}$ and Tuder, 2009- Romania, Lue, Lee and Mclnish (2002) - Singapore. We also find that the $\mathrm{B} / \mathrm{M}$ ratio in UK market showed an opposite sign revealing that the higher the ratio is, the lower will be the subsequent returns in contrast to the findings confirmed by Fama and French (1992, 1998), Daniel and Tittman (1997), Davis, Fama and French (2000), Lam (2002), Tudor (2009).

This study confirms that the size effect on expected stock returns exist only in the UK stock returns reporting a contrasting result with positive sign; the larger (high market equity) size firms earn higher returns than the smaller (low market equity) size firms. Ho, Strange and Piesse (2000) and Leu, Lee and McInish (2002) find that the firms with large market capitalization had lower average returns than firms with small market capitalization and our findings do not support this argument.

This study noticed that the fixed assets growth shows its ability to predict subsequent stock returns only in the LSE stocks while in the CSE it becomes insignificant. This negative sign of this risk factor is justifiable as the overinvestment tendency in fixed assets by the UK firms and investor mis-reaction to assets growth and investors might assume this pattern will persist into the future under-appreciating that returns on assets diminish as the assets size increases. The findings strongly support the findings of Cooper, Gulen and Schill, (2008), Titman, Wei and Xie (2004), and Beneish, Lee, and Tarpley (2001) who find a strong inverse relationship between the firm asset growth and the future stock returns.

Notably, findings confirm a positive effect of the sales growth rate in predicting the future returns in the CSE while it does not perform any significant association in the LSE as a developed market. The investors in Sri Lanka might think that the higher the past sales growth is, the higher will be the subsequent returns via higher dividends streams and the pattern will persist for the future with expectations of higher dividends in the future and demand for more common stocks. Also, the leverage loses its significance in the fitted models in the LSE and the CSE similarly implying its inability to perform as a priced factor in both markets. Thus, we do establish that the risk in an emerging market, like in the developed markets, exerts multi-dimensions.

\subsection{Analysis of the Results of the Macroeconomic and Firm Specific Determinants of Stock Returns in the CSE and the $\mathrm{LSE}$}

The results show that only five macroeconomic variables in Sri Lanka and only three macroeconomic indicators in UK significantly reacted in determining the stock returns in both countries which reveal that the CSE is more sensitive to macroeconomic changes than UK. As expected, and in common with most existing researches, the GDP impact positively on the stock returns in both countries implying that increased cash flows from firm's operations attract more and more investors in both stock markets. This finding confirms the empirical literature that reports a positive correlation in many countries; Humpe and Macmillan, (2007); Ratanapakorn and Shama, (2007) and Mukergy and Naka, (1995), Wonghangpo and Sharma, (2002), Ibrahim and Aziz, (2003).

The study also confirms the negative impact of inflation on the stock returns in both CSE and LSE which reveals that the higher the inflation is in the two countries the lower will be the stock returns in contrast with the generally accepted Fisher effect (1930) which means that the stocks of the CSE and the LSE do not provide effective hedges against the rising inflation. However, the findings strongly support the findings of Gan, Lee, Yong and Zhang (2006), Humpe and Macmillan 
(2007), Boudoukh and Richardson (1993), in developed markets and Ibrahim and Aziz (2003) and Wonghangpo and Sharma (2002) in emerging countries.

The results note that the Sri Lanka as an import-oriented country the currency depreciation has an inverse relationship on stock returns since the cost of input will rise in import companies, hence profits and dividends shrink, as listed in the CSE. This negative relationship supports the findings of Kim (2003)-US, and Ibrahim and Aziz (2003- Malaysia. The UK as an export-oriented country demonstrates a direct relation due to the fact that profits hence dividends will increase in export companies in the LSE. This supports, the findings of Ratanapakorn and Sharma (2007), Phylaktis and Ravazzolo (2005) and Mukherjee and Naka (1995).

It is evidenced that after the civil war Sri Lanka experiences a remarkable growth in the economy and the stock market as well and a huge inflow of FPI is noted. Thus, the positive association between FPI and stock return supports the findings of Anayochukwu (2012) who find that the inflow of the FPI enhances stock market returns. The unemployment rate is another significant risk factor which is priced in the CSE but it fails to exhibit any statistically significant relationship with the UK stock returns although the unemployment rate there is very high during the period under consideration. The rising unemployment rate in Sri Lanka reveals that fewer cash holdings by investors, who do not demand for more stocks thereby paves a less tendency to invest in the stock market; thus, it strongly confirms that Sri Lanka as an emerging market is more likely to respond negatively to rising unemployment rate news whereas the LSE is concerned, it is absent there. This finding is compatible with the findings of Pilinkus and Boguslankas (2009) in Lithuania and inconsistent with Bulmash and Trivoli (1991) in US context. The findings reveal that both the systematic and the unsystematic risk factors perform better in multifactor assets pricing models in explaining the stock return variations not only in the developed but also in the emerging capital markets. The portfolio diversification strategies are not required to eliminate the systematic risk associated with the stock returns.

\section{Conclusion}

This study examines the firm-specific and macroeconomic determinants of Sri Lanka and the UK stock returns and successfully recognizes a comparison and a review of the key findings of the two markets in the frameworks of emerging and developed markets. The study applies a panel data approach in a multifactor assets pricing model framework using the data from both countries. The results reveal differences between the systematic and unsystematic risk factors which are priced in both the LSE and the CSE stocks. However, it is noticed that there are some similarities and dissimilarities of the significant /insignificant risk factors in these two markets. The Sri Lankan stock market as a developing market witnesses risk factors, both the firm, and macro, which explains more stock return variations than the
LSE. Although a comparison was carried out in two different stock markets with different development levels, it can be concluded that both CSE and LSE are more sensitive to macroeconomic changes and the findings of this study do not support the predictions of Fama's (1970) semi-strong form of the market efficiency. Thus, it seems that, based on the publicly available information, the investors can make abnormal profits through stock trading strategies and the multifactor assets pricing models work effectively both in the CSE and LSE.

\section{Acknowledgements}

We would like to thank the National Centre for Advanced Studies and Higher Education for Twenty First Century Project under Ministry of Higher Education for financial supports.

\section{References}

[1] Alam, M., \& Uddin, G.S. (2009). Relationship between Interest Rate and Stock Price: Empirical Evidence from Developed and Developing Countries, International Journal of Business and Management, Vol. 4(3), pp 43-51.

[2] Anayochukwu, O. B. (2012). "The Impact of Stock Market Returns on Foreign Portfolio Investment in Nigeria" IOSR Journal of Business and Management Vol. 2, Issue 4, 10-19 (ISSN: 2278-487X).

[3] Baltagi, B.H., (2013). Econometric Analysis of Panel Data, fifth edition, Wiley, Chichester, UK.

[4] Banz, R.W., (1981). The Relationship Between Return and Market Value of Common Stocks, Journal of Financial Economics, Vol. 9, (1981), pp 3-18.

[5] Basu, S., (1977). Investment Performance of Common Stocks in Relation to their Price Earnings Ratios: A Test of Efficient Market Hypothesis, Journal of Finance, Vol. 32, pp 663-682.

[6] Beneish, M.D., Lee, C.M.C. \& Tarpley, R.L., (2001). Contextual Fundamental Analysis through the Prediction of Extreme Returns, Review of Accounting Studies, Vol. 6, pp 65-189.

[7] Black, F., (1972). Capital market equilibrium with restricted borrowing. Journal of Business, Vol. 45, pp 444-455.

[8] Boudoukh, J. \& Richardson, M., (1993). Stock Returns and Inflation: A Long Horizon Perspective, American Economic Review, Vol. 83, pp 1346-1355.

[9] Bradshaw, M.T., Sloan, R.G. \& Richardson, S.A., (2006). The relation between Corporate Financing Activities, Analysts' Forecasts and Stock Returns, Journal of Accounting and Economics, Vol. 42, pp 53-58.

[10] Breitung, J. (2000). The Local Power of Some Unit Root Tests for Panel Data, in: B. Baltagi (ed.), Nonstationary Panels, Panel Cointegration, and Dynamic Panels, Advances in Econometrics, Vol. 15, JAI: Amsterdam, 161-178. 
[11] Bulmash, S.B., \& Trivoli, G.W., (1991). Time-Lagged Interactions between Stock Prices and Selected Economic Variables, Journal of Portfolio Management, Vol. 17(4), pp 61-67.

[12] Chan, L.K.C., Hamao, Y. \& Lakonishok, J., (1991). Fundamentals and Stock Returns in Japan, Journal of Finance, Vol. 46 (05), pp 1739-1789.

[13] Chan, L.K.C., Lakonishok, J. \& Sougiannis, T., (2001). The Stock Market Valuation of Research and Development Expenditures, Journal of Finance, Vol. 56 (06), pp 2431-2456.

[14] Chen, N., Roll, R., \& Ross, S., (1986). Economic Forces and the Stock Market, Journal of Business, Vol. 59(3), pp 383-403.

[15] Cooper, M.J., Gulen, H. \& Schill, M.J., (2008). Asset Growth and the Cross-Section of Stock Returns, Journal of Finance, Vol. 63(04), pp 1609-1651.

[16] Daniel, K. \&Tittman, S., (1997). Evidence on the Characteristics of Cross Sectional Variation in Stock Returns, The Journal of Finance, Vol. 52(1), pp 1-33.

[17] Davis, J.L., Fama, E.F. \& French, K.R., (2000). Characteristics, Covariances, and Average Returns: 1929 to 1997, The Journal of Finance, Vol. 55 (01), pp 389-406.

[18] Dennis, P., Perfect, S.B., Snow, K.N. \& Wiles, K.W., (1995). The Effects of Rebalancing on Size and Book-to-Market Ratio Portfolio Returns, Financial Analysts Journal, Vol. 51(3) (May-June), pp 47-57.

[19] Doong, S.C., Yang, S.Y. \& Wang, A.T., (2005). The Emerging Relationship and Pricing of Stocks and Exchange Rates: Empirical Evidence from Asian Emerging Markets, Journal of American Academy of Business, Cambridge, Vol. 7(1), pp 118-123.

[20] Fama, E. F., French, K. R., (1998). Value versus growth: The international evidence. Journal of Finance 53, 1975-1999.

[21] Fama, E.F. \& French, K.R., (1988). Permanent and Temporary Components of Stock Prices, Journal of Political Economy, Vol. 96, pp 246-273.

[22] Fama, E.F. \& French, K.R., (1992). The Cross- Section of Expected Stock Returns, The Journal of Finance, Vol. 47(2).

[23] Fama, E.F., (1981). Stock Returns, Real Activity, Inflation, and Money, American Economic Review, Vol. 71, pp 545-565.

[24] Fisher, I., (1930). The Theory of Interest, Retrieved $30^{\text {th }}$ July 2011 from http://www.econlib. org/ library/ YPDBooks /Fisher /fshToI.html.

[25] Flannery, M.J. \&Protopapadakis, A.A., (2002). Macroeconomic Factors Do Influence Aggregate Stock Returns, Retrieved 15 March 2010 from http://papers.ssrn.com/sol3/ papers.cfm? abstract_id=314261, Pacific-Basin emerging markets, Working paper, The Hong Kong Polytechnic University.

[26] Gan, C., Lee, M., Yong, H.H.A., \& Jun, Z., (2006). Macroeconomic Variables and Stock Market Interactions: New Zealand Evidence, Investment Management and Financial Innovations, Vol. 3(4), pp 89.

[27] Gunasekarage, G., Pisedtasalasai, A. and Power, D.M. (2004). "Macroeconomic Influence on the Stock Market: Evidence from an Emerging Market in South Asia", Journal of Emerging Market Finance, Vol. 3 No. 3, pp. 285-304
[28] Harris R.D.F. and E. Tzavalis (1999), ìnference for unit roots in dynamic panels where the time dimension is Öxedî, Journal of Econometrics, 91, 201-226.

[29] Hausman, J.A., (1978). Specification tests in econometrics, Econometrica 46, 1251-1272.

[30] Ho, Y., Strange, R. \&Piesse, J., (2000). CAPM Anomalies and the Pricing of Equity: Evidence from the Hong Kong Market, Journal of Applied Economics, Vol. 32, pp 1629-1636.

[31] Humpe, A., \& Macmillan, P., (2007). Can Macroeconomic Variables Explain Long Term Stock Market Movements? A Comparison of the US and Japan, Centre for Dynamic Macroeconomic Analysis Working Paper Series, Retrieved 20, July 2011 from http://www.st-andrews.ac.uk /economics/ CDMA/ papers/wp0720.

[32] Ibrahim, M., \& Aziz, M., (2003). Macroeconomic Variables and the Malaysian Equity Market: A Rolling through Subsamples, Journal of Economic Studies, Vol. 30(1), pp 6-27.

[33] Kim, K., (2003), Dollar Exchange Rate and Stock Price: Evidence from Multivariate Cointegration and Error Correction model, Review of Financial Economics, Vol. 12, pp 301-313.

[34] Lakonishok, J., Shleifer, A. \& Vishny, R.,(1994). Contrarion Investment, Extrapolation, and Risk, The Journal of Finance, Vol. 49(5), (December), pp 1541-78.

[35] Lam, K.S.K., (2002). The Relationship between Size, Book-to-Market Equity Ratio, Earnings-Price Ratio, and Return for the Hong Kong Stock Market, Global Finance Journal, Vol. 13, pp 163-179.

[36] Leu, S.T., Lee, C.T. \& McInish, T.H., (2002). Stock Returns and Beta, Firms Size, E/P, CF/P, Book-to-Market, and Sales Growth: Evidence from Singapore and Malaysia, Journal of Multinational Finance Management, Vol. 12(3), pp 207-222.

[37] Lintner, J. (1965). The Valuation of Risk Assets and the Selection of Risky Investment in Stock Portfolios and Capital Budgets. Review of Economic Statistics, Vol. 47, pp.13-37.

[38] Luintel, K.B. \& Paudyal, K., (2005). Are Common Stocks a Hedge Against Inflation?, Journal of Financial Research, School of Business and Economics, Working Paper SBE 2005/5.

[39] Markowitz, H., (1952). Portfolio Selection, The Journal of Finance, Vol. 7(1), pp 77-91.

[40] Maysami, R.C., \& Koh, T.S., (2000). A Vector Error Correction Model of the Singapore Stock Market. International Review of Economics and Finance, Vol. 9,pp 79-96.

[41] Maysami, R.C., Howe, L.C., \&Hamzah, M.A., (2004). Relationship between Macroeconomic Variables and Stock Market Indices: Cointegration Evidence from Stock Exchange of Singapore's All-S Sector Indices. Journal Pengurusan, Vol. 24, pp 47-77.

[42] Mishra, A.K., (2004). Stock Market and Foreign Exchange Market in India: Are they Related?, South Asia Economic Journal, Vol. 5(2), September 2004, pp 209-232.

[43] Mukherjee, T. K. \& Naka, A., (1995). Dynamic Relations between Macroeconomic Variables and the Japanese Stock Market: An Application of a Vector Error Correction Model. Journal of Financial Research, Vol. 18, pp 223-237. 
[44] Nasseh, A. \& Strauss, J., (2000). Stock Prices and Domestic and International Macroeconomic Activity: A Cointegration Approach. The Quarterly Review of Economics and Finance; Vol. 40(2), pp 229-245.

[45] Pandey, I.M., (2001). The Expected Stock Returns Of Malaysian Firms: A Panel Data Analysis, (September 2001), IIMA Working Paper, No. 2001-09-01.

[46] Pilinkus, D. and Boguslauskas, V. (2009). The short-run relationship between stock market prices and macroeconomic variables in Lithuania: An application of the impulse response function. Engineering Economics, 5(65), 26-34.

[47] Phylaktis, K., \& Ravazzolo, F., (2005). Stock Prices and Exchange Rate Dynamics, Journal of International Money and Finance, Vol. 24, pp 1031-1053.

[48] Ratanapakorn, O. \& Sharma, S.C., (2007). Dynamic Analysis between the US Stock Returns and the Macroeconomic Variables, Applied Financial Economics, Vol. 17, pp 369-377.

[49] Ross, S.A., (1976). The Arbitrage Theory of Capital Asset Pricing, The Journal of Economic Theory, Vol. 13, pp 341-360.

[50] Hasan, T., Samarakoon, L.P., and Hasan, S., (2000). Stock prices behavior in a less developed market; evidence from Sri Lanka. Journal of Applied Business Research, Vol. 16, No.02, 15-23.
[51] Sharpe, W., (1964). Capital Asset Prices: A Theory of Market Equilibrium under Conditions of Risk, Journal of Finance, Vol. 19, pp 425-442.

[52] Titman, S., Wei, K.C.J. \& Xie, F., (2004). Capital Investments and Stock Returns, The Journal of Financial and Quantitative Analysis, Vol. 39(04), pp 677-700.

[53] Tudor, C., (2009), Price Ratios and the Cross-Section of Common Stock Returns on Bucharest Stock Exchange: Empirical Evidence, Rom. J. Economic Forecast, Vol. 6(2), pp 132-146.

[54] White, C.B., (2000). What P/E Will the U.S. Stock Market Support?, Financial Analysts Journal, Vol. 56(6), November / December 2000, pp 30-38.

[55] Wickremasinghe, G. (2011). "The Sri Lankan stock market and the macroeconomy: an empirical investigation", Studies in Economics and Finance, Vol. 28 Issue 3, pp.179- 195.

[56] Wongbangpo, P. \& Sharma, C.S., (2002). Stock Market and Macroeconomic Fundamental Dynamic Interactions: ASEAN-5 Countries, Journal of Asian Economics, Vol. 13, pp $27-5$.

\footnotetext{
1 Two of the current best theories which offer a thorough foundation for computing the tradeoff between risk and return are the Capital Asset Pricing Model (CAPM) and the Arbitrage Pricing Theory (APT) and the first capital assets pricing model was developed by Sharpe (1964), Lintner (1965) and Black (1972) which is a single factor model based on single period mean variance framework of Markowitz (1952) while the APT was developed by Ross (1976) as a multifactor return generating model as an alternative to the CAPM.

2 Other researchers attempted to find the relationships in New Zealand (Gan et al., 2006), in Singapore (Maysami and Koh, 2000; Maysami et. al., 2004) in India (Mishra, 2004), in Malaysia (Ibrahim and Aziz, 2003).

3 Firstly, the Banks, Finance and Insurance companies were excluded since these companies are generally governed by different rules and practices with regard to financing, and also, their financial reporting differs from that of the non-financial firms. Secondly, the thirteen-year period from 2000 to 2012 was covered for the study. A balanced sample consisting of companies whose financial data are available for all the thirteen years and are continuously listed on the CSE for all these thirteen years was used. The delisted and the newly listed companies were eliminated from the sample. Next, the companies whose shares have been traded at least for six months were selected as frequently trading companies, hence high liquid companies in the CSE.

4 The companies in the sectors, namely, Bank \& Finance, Chemicals, Information Technology, Power \& Energy, Services, and Telecommunication were not qualified for the final sample as per the sample selection criteria; hence the final sample consists of 14 sectors in the CSE.

5 For this study, we considered Harris-Tzavalis (1999) test and Breitung (2000) tests because they are suitable when number of periods, T, (years in our case) is small and the number $\mathrm{N}$ of individuals (firms in our case) is large. The results are not reported here for brevity.

6 See the fixed and random effects regression output tables for robust standard errors.

7 See table 1 for rejection of the null hypothesis in favor of fixed firm effect models.

8 There were 287 companies listed in the CSE as at $31^{\text {st }}$ December 2013 when the final sample companies were selected.

9 Fama and French (1992) in their two factor model find that firms with higher B/M ratios subsequently have higher returns.

10 Based on the panel data approach, the main concern is geared towards ascertaining the firm specific and macroeconomic determinants of the stock returns in the CSE and the stock returns were regressed on both selected macroeconomic indicators and firm fundamentals eliminating the multicolinearity issue.

11 However, past sales growth rate and leverage appeared to have with the expected sings though they do not impact significantly.
} 